\title{
Application of Time and Motion study for Performance Enhancement of Building Construction Industry
}

\author{
Dr. Krupesh A. Chauhan, Rushabh A. Shah
}

\begin{abstract}
Construction industry is, as we all know growing at very fast rate to match the current and innovative requirements. Still there are so many reasons of delaying and cost overruns in construction industry. Out of which one of the main reason is Lean waste. These wastes are always hidden and we often neglect or do not give them importance for any analysis or scheduling work. To identify and to avoid those wastes, lean tools need to be implemented on such kind of projects. In this study lean tool in terms of Time and motion study is applied on plastering work of Three building construction sites of Surat, Gujarat, India (Site 1: Pratham, Site 2: IFM, Site 3: Celebration Home). Leant tool is applied on plastering work, which is divided in 3 Main activities, and those main 3 activities further divided in 9 different part. Time study is a direct and continuous observation of a task, using a timekeeping device (e.g., decimal minute stopwatch, computer-assisted electronic stopwatch, and videotape camera) to record the time taken to accomplish a task. Motion studies are performed to eliminate waste. Data was collected for sites during different time and of different types of labors. The analysis result show that some of the activities are having higher time than the average time that will force the task to overruns.
\end{abstract}

Index Terms: Lean Tool, Motion Study, Plastering work, Time Study.

\section{INTRODUCTION}

Time and motion study (also referred to as motion and time study, the terms are used interchangeably) is the scientific study of the conservation of human efforts in the search for the most efficient method of doing a task with optimum output. A fascination with the word "efficiency" began in the late $19^{\text {th }}$ and early $20^{\text {th }}$ centuries when it was considered one of the most important concepts ${ }^{[27]}$. Time study began in the 1880s as a means of wage-rate setting by Frederick W. Taylor, who is called as the "father of scientific management." It consists of a wide variety of procedures for determining the amount of time required, under certain standard conditions of measurement, for tasks involving some human activity. Motion study was introduced by Frank B. Gilbreth and Lillian M. Gilbreth and consists of a wide variety of procedures for the description, systematic analysis, and means of improving work methods ${ }^{[13]}$.

It is difficult to separate these two aspects completely. Therefore, the combined term usually refers to all three

Revised Manuscript Received on June 26, 2019.

Dr. Krupesh A. Chauhan, Professor, Civil Engineering Department, S. V. National Institute, Surat, Gujarat, India.

Rushabh A. Shah, Research Scholar, Civil Engineering Department, S. V. National Institute, Surat, Gujarat, India. phases of the activity: method determination, time appraisal, and development of material for the application of these data. Frank and Lillian also broadened scientific management by including the human element, therefore using psychology to gain the cooperation of employees. Motion and time analysis could be used to help find a preferential way of doing the work and could assist in effectively managing or controlling the activity. This approach has been successfully applied to factories, hospitals, department stores, housework, banks, cafeteria work, libraries, music, and too many other human activities. For instance, factories have used it to reduce wasted time and improve the time to compete a task, while banks use it to help team members reach their sales goals. However, the goal of a time and motion study is not simply efficiency. These studies are done to create a baseline that can be used in the future when evaluating procedural, equipment, or personnel changes. Despite of so much success in other industries still this has not been much utilized in construction industry so in this study an attempt has been made to utilize time and motion study in building construction industry of Surat city to find out the optimum time required for plastering work. This study is based only on three case study so the data is only taken from those sites and comparison of those sites only done for the analysis work.

\section{LITERATURE REVIEW}

Rajshri Shrishirmal, R.R. Salgude ${ }^{[2]}$ has measure the productivity of the various construction activities like Concrete work, Masonry work and the focus is emphasized on how to apply time and motion study and statistical analysis to various construction processes they suggested that optimum number of personnel for concreting activity and rebar placement is 12 to 14 on the work location. The optimum number of human resources assigned to the construction activities leads to economy, reduction in time and thus quality work is obtained.

Neelmani ${ }^{[23]}$ has carried out Motion and time study to reduce and control costs, improve working conditions and environment, and to motivate people. The basic purpose of this research paper is to improve the work quality and to reduce chances of waste generation for the optimum productivity.

Abdul Talib Bon, Aliza Ariffin ${ }^{[1]}$ has carried out the motion study. Study reveals that motion study has the greatest potential for savings in cost, time and quality. They suggest that we can apply 
motion study by eliminating the task or combining the task with some other task. We can rearrange the elements of work to reduce the work content and we can simplify the operation by moving part.

Puniavathi Puranam, Pramila. \& R. Adavi ${ }^{[25]}$, has used time and motion study in manufacturing sector for higher productivity in organizations which at the end leads to national prosperity and better standard of living for the whole community.

Jacob Je-Chian Lin,Wei-Han Hung,Shih-Chung Kang ${ }^{[15]}$ in their research described a motion planning and coordination method for mobile construction machinery. The method includes four-steps that are known as follows 1) model development, 2) configuration space construction, 3) path finding and 4) machine coordination.

Yvan J. Beliveau, Shrikant S. Dixit, Taylan Dal and AymanA. Morad ${ }^{[29]}$, describes the fundamental philosophy of the system, specifically, the strategy of the required path-planning and dynamic behavior modeler. Current work in these areas is presented. MTMP (Multi Task Motion Planning) help to provide a robust tool for multitask motion planning with several applications, typically in the construction industry. The underlying concepts can useful in a variety of material-handling operations.

Vipulkumar V. Mori Yuvrajsinh B. Kanchava Pravin A. Karetha Manish B. Charola ${ }^{[28]}$ in their paper identified how simple methods can be used to improve the rate of production in vehicle assembly. By making simple changes to the process, it can reduce the time taken for each operation to improve the production rate. Productivity improvement is achieved through analyzing the current method by eliminating un-necessary movements by use of standard operating procedure, reducing cycle time and providing appropriate solutions to various problems during the assembly of components to improve productivity.

Jigar H. Balar, Hiren A. Rathod, Rushabh Shah ${ }^{[18]}$ in this study they have took projects for time and motion study considering ten selected activities on field for time and motion study. Data will be collected for all activities under time study on field using stopwatch, average time will be estimated, and then further analysis under motion study to determine the optimum time required for performing selected operations and identify the extra time consumed on site. The analysis result will show that almost all the activities consumed more time more than what is required for actual work.

\section{NEED OF STUDY}

Despite of many advanced tools and technologies available for scheduling and planning many of the construction projects faces the issue of time and cost overruns. The time spent on performing action has direct impact on resources i.e. more time to complete activity is equal to wastage of more money and more energy. Which will affect the cost of construction project also. In a way time and motion study, determine the overall actual time and total ineffective time for completing the task. By which we can identify the ineffective time and we can reduce that in future projects. Hence, Time and Motion study is used to determine the best method for completing action within the required time.

In order to achieve high quality level in construction industry and improve the performance, feasibility and suitability of different new philosophies in construction projects have been studied in recent years, but due to the various processes associated with construction projects, their complexity, and lack of specific metrics, this issue is still questionable and demands further studies..

\section{RESEARCH METHODOLOGY}

\section{A. Time Study}

Three sites of Surat (India) building construction industry are selected and plastering work was considered for time study. The whole plastering work was divided in to three part i.e. Material collection, lead-time and application time. Further, that three main task was broken in to different nine segment according to the study requirement. Time study was done using Stop watch and note pad. Time was considered start when the materials were started to be collected for the sieve analysis and stopwatch was stopped when the finishing work was done.

\section{B. Motion Study}

As all the construction site were at different location and having different kind of labors so motion of those all the labors were studied in motion study. Those sites which were having safety and all other kind of requirements which can be useful for the ease of labors are having less time of completion compared to average time.

\section{DATA COLLECTION AND ANALYSIS}

\section{A. Data Collection}

Collection of data has been done by personal site visits at the time of plastering work at different time interval on all the three sites. Data was collected in the form of Time study table, which includes all the details of plastering work process. Time was measured in seconds. Two-stop watch was used for the time study. First Stopwatch was started when the first task was started and it was stopped when the overall work is done. Second stopwatch was used to measure the time for each component of the entire three task and all the nine segments.

- Time measured by Stop watch $1=\mathrm{T}_{1}$

- Time measured (Summation of all segments) by stop watch $2=\mathrm{T}_{2}$

- Unnecessary time $=\mathrm{T}_{1}-\mathrm{T}_{2}$

\section{B. Data Analysis}

Motion study was used to find out why the unnecessary time was there in performance of activity for that following operational time calculation table was used and brain storming with expert was done to differentiate the activities for basic and ineffective activities. Basic activities are those activities, which must be done for completion of the task. On the other hand ineffective work are those which adds time in overall activities but do not add any value to the overall performance.

\section{RESULT ANALYSIS}




\section{A. Time Study}

First, the permission was taken to carry out the research work by collecting the data from the site and commercial site located at various area in Surat city Residential Sites are.1) Pratham Ganesa (A), 2) International Fashion Market (IFM) (B), 3) Celebration Home (C), located at Surat.

Time study was done on the ongoing activity of plastering on all sites during its execution work and analyzed using MS Excel and the analyzed data with comparison of all the result is shown in table given below.

Table 1: Comparison of Plastering Data of Various Sites

\begin{tabular}{|c|c|c|c|c|c|}
\hline Main & $\begin{array}{c}\text { Sub } \\
\text { Activity }\end{array}$ & $\mathbf{A}$ & B & C & Avg. \\
\hline \multirow{6}{*}{ 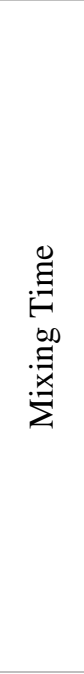 } & $\begin{array}{l}\text { Time to } \\
\text { Collect } \\
\text { Material }\end{array}$ & 50.70 & 37.20 & 27.20 & 38.37 \\
\hline & $\begin{array}{l}\text { Transfer } \\
\text { Time To } \\
\text { Lift } \\
\text { Trolley }\end{array}$ & 39.50 & 27.90 & 24.50 & 30.63 \\
\hline & $\begin{array}{l}\text { Return } \\
\text { Time }\end{array}$ & 33.80 & 28.90 & 22.60 & 28.43 \\
\hline & $\begin{array}{l}\text { Total } \\
\text { Time }\end{array}$ & 124.00 & 94.00 & 74.30 & 97.43 \\
\hline & $\begin{array}{l}\text { One } \\
\text { Complete } \\
\text { Cycle } \\
\text { Time }\end{array}$ & 214.45 & 183.95 & 179.75 & 192.72 \\
\hline & $\begin{array}{l}\text { Ineffective } \\
\text { Time }\end{array}$ & 90.45 & 89.95 & 105.45 & 95.28 \\
\hline \multirow{6}{*}{ 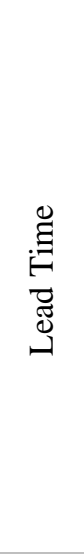 } & $\begin{array}{l}\text { Lifting } \\
\text { Time }\end{array}$ & 27.40 & 22.70 & 33.70 & 27.93 \\
\hline & $\begin{array}{l}\text { Unloading } \\
\text { Time }\end{array}$ & 95.90 & 107.90 & 117.90 & 107.23 \\
\hline & $\begin{array}{l}\text { Return } \\
\text { Time }\end{array}$ & 24.20 & 18.30 & 32.80 & 25.10 \\
\hline & $\begin{array}{l}\text { Total } \\
\text { Time }\end{array}$ & 147.50 & 148.90 & 184.40 & 160.27 \\
\hline & $\begin{array}{l}\text { One } \\
\text { Complete } \\
\text { Cycle } \\
\text { Time }\end{array}$ & 631.00 & 626.30 & 523.80 & 593.70 \\
\hline & $\begin{array}{l}\text { Ineffective } \\
\text { Time }\end{array}$ & 483.50 & 477.40 & 339.40 & 433.43 \\
\hline \multirow{6}{*}{ 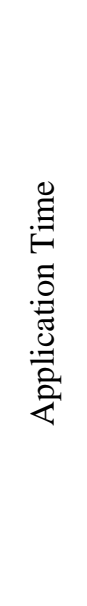 } & $\begin{array}{l}\text { Mixing } \\
\text { Time }\end{array}$ & 55.80 & 79.80 & 106.10 & 80.57 \\
\hline & $\begin{array}{l}\text { Transfer to } \\
\text { application } \\
\text { location }\end{array}$ & 6.70 & 7.10 & 7.10 & 6.97 \\
\hline & $\begin{array}{l}\text { Return } \\
\text { Time }\end{array}$ & 6.30 & 2.90 & 2.90 & 4.03 \\
\hline & $\begin{array}{l}\text { Total } \\
\text { Time }\end{array}$ & 68.80 & 89.80 & 116.10 & 91.57 \\
\hline & $\begin{array}{l}\text { One } \\
\text { Complete } \\
\text { Cycle } \\
\text { Time }\end{array}$ & 82.90 & 105.40 & 156.40 & 344.70 \\
\hline & $\begin{array}{l}\text { Ineffective } \\
\text { Time }\end{array}$ & 14.10 & 15.60 & 40.30 & 23.33 \\
\hline
\end{tabular}

\section{B. Motion Study}

After doing the time study on plastering work second task is to do motion study of the work. For that brainstorming work is done on why ineffective time was there in all the three component of plastering work after doing the brainstorming it was observed that there are so many reasons for that which were than divided in three part i.e. Productivity, Methodology and Human resources. Further, their sub reasons were also studied. Which are shown in the table below.

Table 2: Operational Time Calculation

\begin{tabular}{|c|c|c|}
\hline \multirow{4}{*}{$\begin{array}{c}\text { Total time of } \\
\text { operation under } \\
\text { existing conditions }\end{array}$} & $\begin{array}{c}\text { Basic work } \\
\text { content }\end{array}$ & $\begin{array}{l}\text { Basic work content of } \\
\text { product and operation }\end{array}$ \\
\hline & \multirow{3}{*}{$\begin{array}{c}\text { Total } \\
\text { ineffective } \\
\text { time }\end{array}$} & $\begin{array}{l}\text { Work content added by } \\
\text { poor product design or } \\
\text { material utilization }\end{array}$ \\
\hline & & $\begin{array}{l}\text { Work content added by } \\
\text { inefficient method of } \\
\text { manufacture or } \\
\text { operation }\end{array}$ \\
\hline & & $\begin{array}{l}\text { Ineffective time } \\
\text { resulting from human } \\
\text { resources contribution }\end{array}$ \\
\hline
\end{tabular}

Table 3: Basic and Additional Work Content

\begin{tabular}{|c|c|c|c|}
\hline \multirow{6}{*}{$\begin{array}{l}\text { Total Time } \\
\text { Of } \\
\text { Operation } \\
\text { Under } \\
\text { Existing } \\
\text { Conditions }\end{array}$} & $\begin{array}{l}\text { Basic Work } \\
\text { Content }\end{array}$ & $\begin{array}{l}\text { Basic Work } \\
\text { Content }\end{array}$ & $\begin{array}{l}\text { Basic Work } \\
\text { Content Of } \\
\text { Product And } \\
\text { Operation }\end{array}$ \\
\hline & \multirow{5}{*}{$\begin{array}{l}\text { Total } \\
\text { Ineffective } \\
\text { Time }\end{array}$} & $\begin{array}{l}\text { Poor Design } \\
\text { and Frequent } \\
\text { Design } \\
\text { Changes }\end{array}$ & \multirow{3}{*}{$\begin{array}{l}\text { Work } \\
\text { Content } \\
\text { Added By } \\
\text { Poor Product } \\
\text { Design Or } \\
\text { Material } \\
\text { Utilization }\end{array}$} \\
\hline & & Wastage & \\
\hline & & $\begin{array}{l}\text { Materials not } \\
\text { According to } \\
\text { Standards or } \\
\text { Specifications }\end{array}$ & \\
\hline & & $\begin{array}{l}\text { Improper } \\
\text { Utilization of } \\
\text { Available } \\
\text { space }\end{array}$ & \multirow{2}{*}{$\begin{array}{l}\text { Work } \\
\text { Content } \\
\text { Added By } \\
\text { Inefficient } \\
\text { Method Of } \\
\text { Manufacture } \\
\text { Or Operation }\end{array}$} \\
\hline & & $\begin{array}{l}\text { Inadequate } \\
\text { Materials } \\
\text { Handling }\end{array}$ & \\
\hline
\end{tabular}




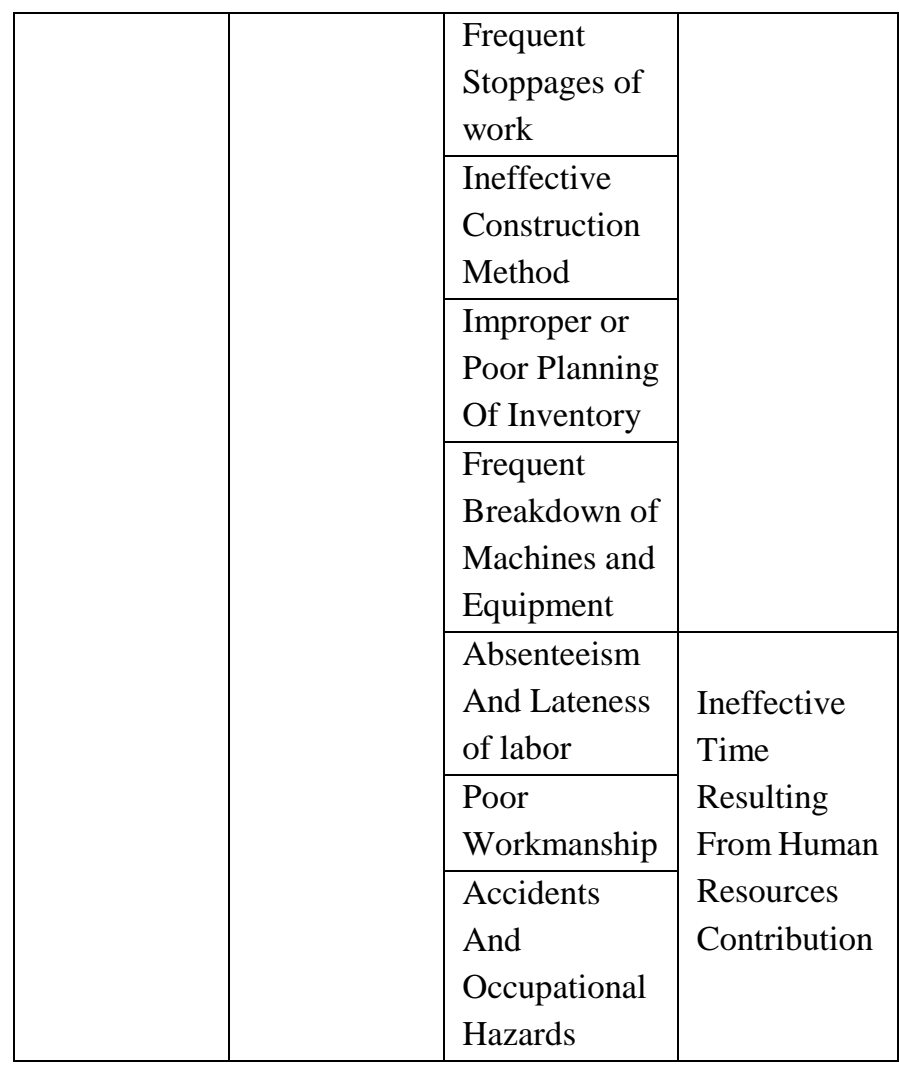

\section{CONCLUSION}

From the data analysis, it can be clearly seen that Time and Motion study is very useful to identify the ineffective time and reasons of that ineffective time.It was observed from the data that in all the sites there is ineffective time in all the part of the plastering work.Out of three sites site A and Site B are having less ineffective time compared to site C.Out of all three section of plastering work major ineffective time was found in lead-time and mixing time.Application time, which is known to be the main part, is having less ineffective time compared to other.No site is showing no ineffective time, which indicates that there is much need to control that to avoid overruns in the projects.From the motion study, it was found that that ineffective time is due to three major issues i.e. Due to Poor Design, Methodologies and Human Resources.So if we somehow able to reduce that factors we can avoid all the issues and we can improve the productivity of the construction work.

\section{FUTURE SCOPE}

In this study, only plasterwork was taken for the Time and Motion study in future all the activity like Concreting work, Masonry work etc. can be taken for the analysis.In addition, Cost calculations can be done by correlating time delay and analytical model can be developed.

\section{ACKNOWLEDGMENT}

Authors are very thank full to the SVNIT, Surat for giving opportunity to do the research in the institute. Authors are also heartiest thankful to all the site owners and respondents for giving theory feedback and making this research possible.

\section{REFERENCES}

1. Abdul Talib Bon, Aliza Ariffin. An Impact Time Motion Study on Small Medium Enterprise Organization.

2. Adnan Enshassi, Sherif Mohamed, Ziad Abu Mustafa1 and Peter Eduard Mayer (2007) Factors affecting labour productivity in building projects in the Gaza strip. J. of Civil Engg and Management .p245-254

3. Ann Hendrich, Marilyn Chow, Boguslaw A. Skierczynski, Zhenqiang Lu (2008). A 36 - Hospital Time and Motion.

4. B. Kumar (1999). Industrial Engineering. Khanna Publishers, Delhi.

5. Brian Price (1989). Frank and Lillian Gibreth and the Manufacture and Marketing of Motion Study, 1908 - 1924.

6. Business and Economic History, Second Series, Volume Eighteen, 1989 Business History Conference ISSN 0849.

7. Eok Su Sim, Hyoung Gon Lee, Jung Chul Lee, Jin Woo Park (2004). Efficient Work Measurement System.

8. Ferguson, David S., Don't Call it "time and motion study", IIT Solutions, Norcross. May 1997. Vol. 29, Issue 5.

9. Finkler, Steven A., A Comparison of work-sampling and time-and-motion techniques for studies in health services research, Health Service Research, Chicago. Dec 1993. Vol. 28, Issue 5.

10. Foster (2003). Operational Management - Time and Motion Study.ppt.

11. Fred E. Meyers (1992). Motion and Time Study - Improving Work Methods and Management.

12. Grace Au, Ray J. Paul (1993). Visual Interactive Modelling: A Pictorial Simulation Specification System, European.

13. Gilbreth, Frank B. Motion Study: A Method for Increasing the Efficiency of the Workman. Whitefish, MT: Kissenger Publishing, 2008.

14. H. Randolph Thomas (1991) Labor Productivity and work sampling the bottom-line, J.Cons. Eng. Management., p.p-423-444.

15. Jacob Je-Chian Lin,Wei-Han Hung,Shih-Chung Kang, American Society of Civil, Engineers, DOI:10.1061/(ASCE)CP.1943-5487.0000408,2014.

16. Jay Heizer and Barry Render (2006). “Operations Management” Eight Edition, Pearson Education.

17. Jeffrey S. Smith (2003). Survey on the Use of Simulation for Manufacturing System Design and Operation.

18. Jigar H. Balar, Hiren A. Rathod, Mr. Rushabh Shah, IJSRD International Journal for Scientific Research \& Development| Vol. 6, Issue 03, 2018 | ISSN (online): 2321-0613.

19. Koehler, Kenneth G., Time Cost Analysis, CMA, Hamilton. May 1992. Vol. 66, Issue 4.

20. Management Thought', Management \& Organisational History, vol. 6 , no. 2, pp. 145-161.

21. Marvin E. Mundel and David L. Danner (1994). Motion and Time Study - Improving Productivity, Seventh Edition.

22. M.N.Pal, A.K.Chatterjee Indian Adaptation Introduction to Work Study. International Labour Office, Geneva

23. NEELMANI • September 21, 2013 • Big civil engineering projects, Civil Engineering Projects, Editorial

24. O. C Jensen, S. Stage, P.Noer (2004). Injury and Time Studies of Working Process in Fishing. Journal of Safety Of Manufacturing Systems, Vol. 22 / No 22003 Pages 157 - 171

25. Puniavathi Puranam, Pramila. \& R. Adavi, Time and Motion Study, Analysis Through Statistics.

26. Ralph M. Barnes (2001). Motion and Time Study - Design and Measurement of Work. Seventh Edition. John Wiley and Sons Inc.J. Jones.

27. Rajshri Shrishirmala, R. R. Salgude (2015), "Time And Motion Study of a Residential Site", International Journal of Innovative and Emerging Research in Engineering, ISSN: 2394 - 3343

28. Vipulkumar V. Mori1 Yuvrajsinh B. Kanchava2 Pravin A. Karetha3 Manish B. Charola4, IJSRD - International Journal for Scientific Research \& Development| Vol. 3, Issue 02, 2015 | ISSN (online): 2321-0613

29. Yvan J. Beliveau, Shrikant S. Dixit, Taylan Dal and AymanA. Morad, ASCE 119:180-191( 1993).

\section{AUTHORS PROFILE}

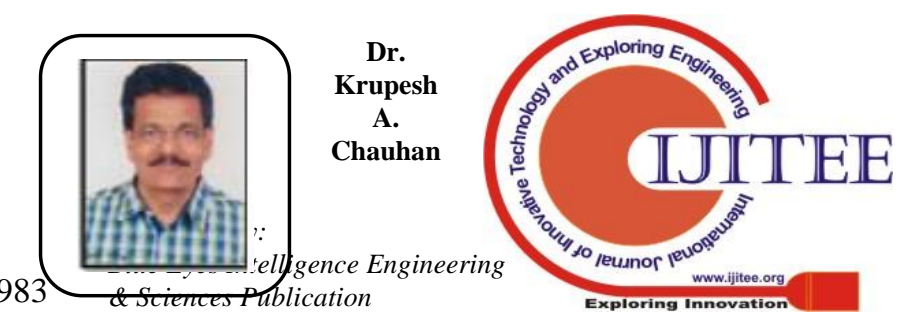


is currently working as professor in S. V. National Institute of Technology, Surat, Gujarat, India. He has published many research papers in various reputed National / International Conferences and Journals. He has also published various books on the current issues and challenges. He is the member of various organizations such as IGBC, ISTE, IE. He has supervised many M. Tech. and PhD Students till date.

Rushabh A. Shah is PhD Scholar in S. V. National Institute of Technology, Surat, Gujarat, India. He has published many research papers in various reputed National / International Conferences and Journals. 